\title{
Characterization of Two New Isolates of Mushroom-Shaped Budding Bacteria
}

\author{
PATRICIA M. STANLEY, ${ }^{1}$ RICHARD L. MOORE, AND JAMES T. STALEY \\ Department of Microbiology and Immunology, University of Washington, Seattle, Washington 98195, and \\ Division of Pathology, Faculty of Medicine, University of Calgary, Calgary, Alberta
}

\begin{abstract}
Two new strains of mushroom-shaped budding bacteria were isolated from a pulp mill oxidation lagoon. These isolates were morphologically similar to previous isolates from England and Russia. However, the carbon source utilization patterns and phage typing by newly isolated phages indicated that the four strains were not identical to one another. This was confirmed by deoxyribonucleic acid (DNA)/DNA homology studies in which reference DNA from a lagoon strain exhibited 39,41 , and $85 \%$ homologies with the other strains. Homology studies indicated that the mushroom-shaped budding bacteria are different from the members of the presently recognized genera of budding bacteria.
\end{abstract}

Budding bacteria reproduce by forming small outgrowths, or buds, at specific locations on the surfaces of mother cells. In the genera $\mathrm{Hy}$ phomicrobium, Rhodomicrobium, Hyphomonas, and Pedomicrobium, buds are produced at the ends of prosthecae; in other budding bacteria, buds are formed directly from the mother cells. Among this latter group are Gemmiger formicilis (2), Rhodopseudomonas acidophila, Pasteuria ramosa, Anacalomicrobium adetum, and Nitrobacter winogradskyi (1). In 1971, Whittenbury and Nicoll (14) described a new budding bacterium, designated as strain muM, which resembled a mushroom during some stages of its growth cycle. A similar organism, strain muMA, was subsequently isolated by Namsaraev and Zavarzin (8).

Presented here are a report of the isolation and characterization of two additional strains of mushroom-shaped budding bacteria and a discussion of the relationship of these bacteria to other budding bacteria.

\section{MATERIALS AND METHODS}

Bacterial strains and media. Strains WAL-4 and WAL-13 were isolated from the waste aeration lagoon of the Weyerhaeuser Co. Everett Kraft Mill, Everett, Wash. Strains muM (14) and muMA (8) were furnished by C. S. Dow, the University of Warwick, Coventry, England. Hyphomicrobium strain T37 was supplied by K. C. Marshall, the University of New South Wales, Kensington, Australia (12).

Cultures were routinely maintained in the complex medium MMB (11). Cells for deoxyribonucleic acid (DNA) extraction were grown in $0.3 \%$ glucose and $0.15 \%$ each of peptone and yeast extract plus

\footnotetext{
${ }^{1}$ Present address: Department of Microbiology, University of Minnesota, Minneapolis, Minn. 55455.
}

vitamins (10) and basai salts solution (MS) (13) with the $\mathrm{NaMoO}_{4} \cdot 2 \mathrm{H}_{2} \mathrm{O}$ concentration reduced to $19 \mathrm{mg} /$ liter. For labeling of DNA, cells were grown in $0.3 \%$ glucose and $0.3 \%$ Casamino Acids (Difco) plus vitamins and basal salts. At about three generations before stationary phase $\left.(19 \mathrm{~h}){ }^{3} \mathrm{H}\right] \mathrm{adenine}$ was added to a final concentration of $3.3 \mu \mathrm{Ci} / \mathrm{ml}$.

Carbon source utilization. The abilities of the strains to use a variety of combined carbon and energy sources were tested using a medium containing $0.07 \mathrm{~g}$ of $\mathrm{K}_{2} \mathrm{HPO}_{4}$ per liter and $0.25 \mathrm{~g}$ of $\left(\mathrm{NH}_{4}\right)_{2} \mathrm{SO}_{4}$ per liter plus $\mathrm{MS}$ and vitamins. Carbon compounds were present at a concentration of $0.1 \%$ (wt/vol) except for methylamine-hydrochloride, formate, and $\mathrm{NaHCO}_{3}$ at $20 \mu \mathrm{M}$ and methanol at 50 $\mu \mathrm{M}$. The inoculum size for the carbon source tests was $10^{6}$ to $2 \times 10^{6}$ cells per $\mathrm{ml}$ ( $1 / 120$ dilution of a late-log-phase culture $[36 \mathrm{~h}]$ ), yielding a final culture volume of $6 \mathrm{ml}$.

Morphology and division cycle. For the slide culture studies, a thin layer of molten MMB agar was spread on a microscope slide. After the agar had solidified and dried slightly, a drop of a log-phase (24 h) culture of cells was spread on the surface. The agar was trimmed to a diameter approximately half the length of the surmounting cover-slip edges. With a Zeiss Ultraphot equipped with a $100 \mathrm{X}$ Neofluar objective, time-sequence photomicrographs were taken of cells near the edge of the agar.

Whole cells were examined with a JEM-100B electron microscope at $60-\mathrm{kV}$ acceleration voltage. Cells were harvested from a logarithmically growing culture $(24 \mathrm{~h})$, placed on 200-mesh Formvar-coated stainless steel grids, and stained with $2 \%$ phosphotungstic acid.

Phage isolation. Water from the pulp mill aeration lagoon was filtered through a $0.22-\mu \mathrm{m}$ membrane filter (Millipore Corp.). Equal volumes of this filtered water and MMB were mixed and inoculated with either strain WAL-4 or WAL-13. After shaking in a water bath at room temperature for $48 \mathrm{~h}$, a sample $(0.5 \mathrm{ml})$ was overlaid in $3.5 \mathrm{ml}$ of MMB medium containing $0.5 \%$ agar. Isolated plaques were twice 


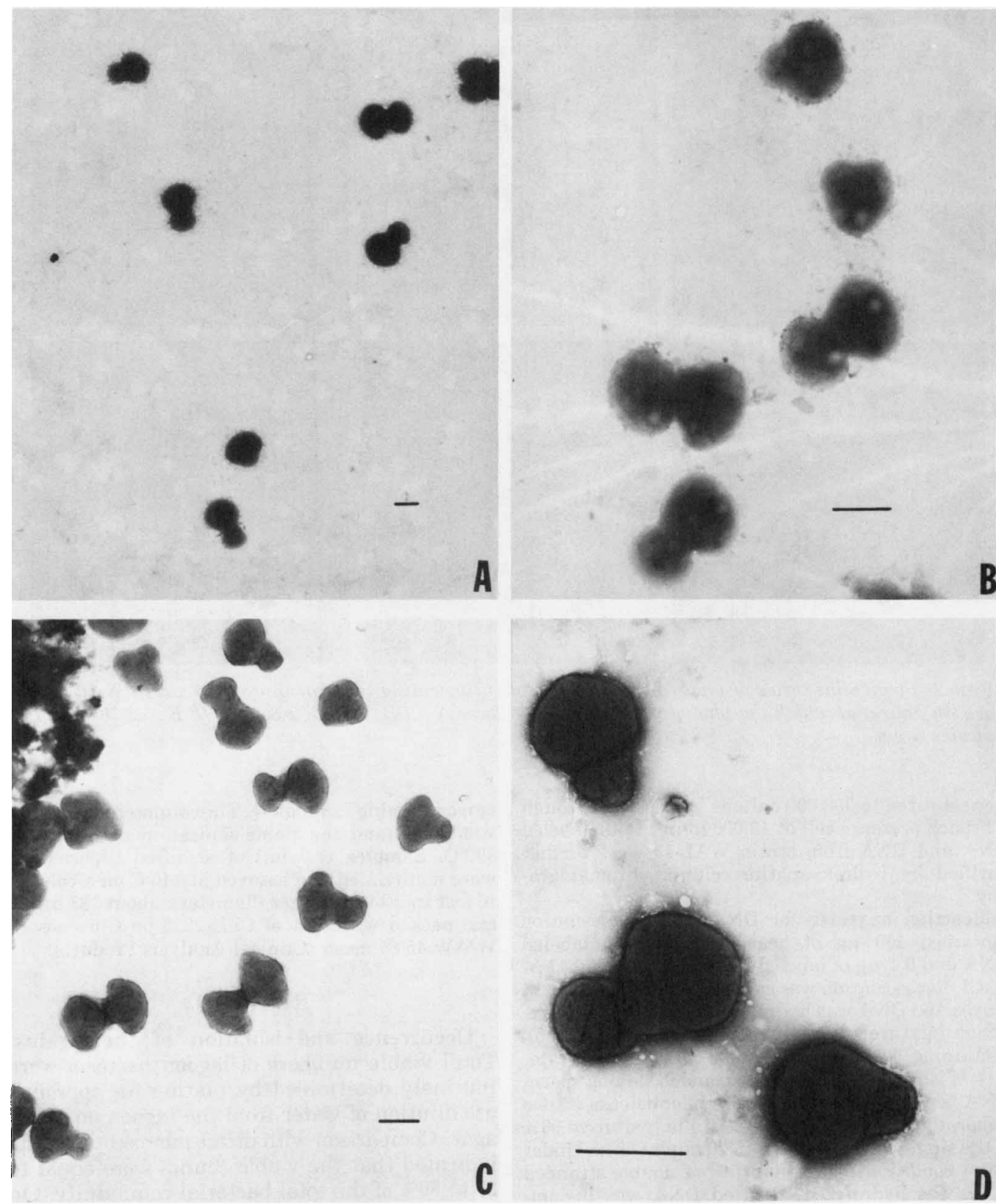

Fig. 1. Electron micrographs of mushroom-shaped budding bacteria. A, WAL-4; B, WAL-13;C, muM;D, muMA. Bar indicates $1 \mu \mathrm{m}$.

replated to insure purity. In the determination of host ranges, the bacterial strains were plated in overlay agar, and drops of phage suspension were placed on top of the overlay.

DNA extraction, heteroduplex formation, and determination of base composition. Both labeled and nonlabeled cells were harvested in early stationary phase $(24-72 \mathrm{~h})$ by centrifugation and washed twice with saline-ethylenediaminetetraacetic acid (EDTA) ( $0.15 \mathrm{M}$ sodium chloride and $0.1 \mathrm{M}$ EDTA [pH 8.O]). The pellets were frozen and stored prior to extraction. The cells were suspended in SSC $(0.15 \mathrm{M}$ sodium chloride, $0.015 \mathrm{M}$ sodium citrate) with 100 $\mu \mathrm{g}$ of Pronase per $\mathrm{ml}$ and $0.2 \%$ sodium lauryl sulfate (SLS) and incubated for $16 \mathrm{~h}$ at $37^{\circ} \mathrm{C}$. The DNA was purified by the method of Marmur (5). All DNAs 

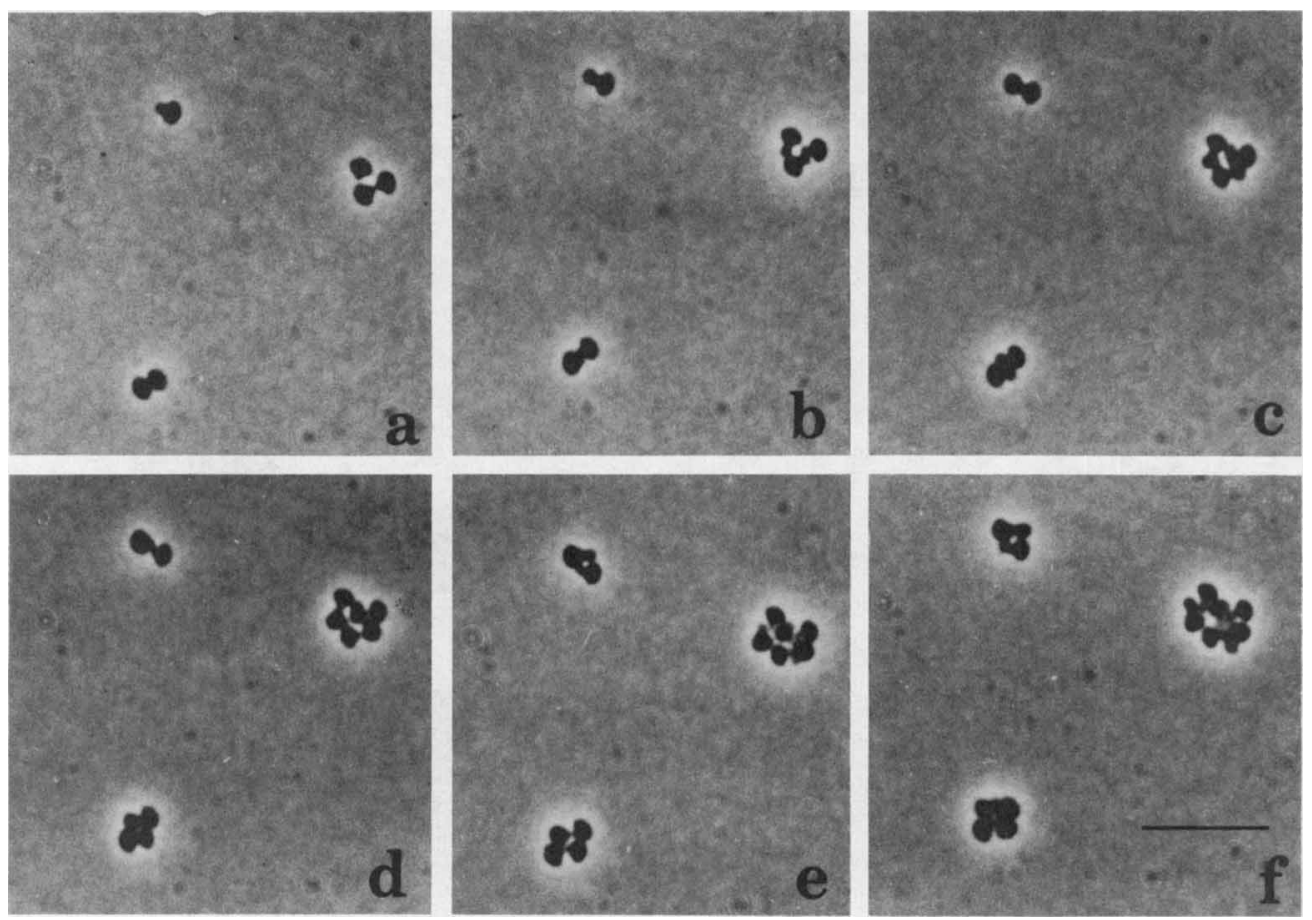

FIG. 2. Sequential series of phase photomicrographs illustrating the growth cycle of strain WAL-4. The times (in hours) at which the photographs were taken were $A, 0 ; B, 1.5 ; C, 2.8 ; D, 4.0 ; E, 5.1 ; F, 6.0 . B a r$ indicates $5 \mu \mathrm{m}$.

were sheared to 300,000 daltons by passage through a French pressure cell at $15,000 \mathrm{lb} / \mathrm{in}^{2}$. Radiolabeled DNA and DNA from strain WAL-13 were further purified by hydroxyapatite column chromatography.

Reaction mixtures for DNA/DNA reassociation contained $150 \mu \mathrm{g}$ of heat-dissociated nonlabeled DNA and $0.1 \mu \mathrm{g}$ of labeled DNA in $1.0 \mathrm{ml}$ of $0.17 \mathrm{M}$ $\mathrm{NaCl}$. Reassociation was carried out at $72^{\circ} \mathrm{C}$ for $16 \mathrm{~h}$. Unreacted DNA was hydrolyzed by adding to the reaction mixture $1.0 \mathrm{ml}$ of enzyme solution ( $\mathrm{pH} \mathrm{4.5)}$, containing $0.2 \mathrm{mM} \mathrm{ZnSO}, 0.06 \mathrm{M}$ sodium acetate, $0.17 \mathrm{M} \mathrm{NaCl}, 40 \mu \mathrm{g}$ of single-stranded salmon sperm DNA per $\mathrm{ml}$, and sufficient $\mathrm{S} 1$ endonuclease (Miles Laboratories Inc., Kankakee, Ill.) to hydrolyze $96 \%$ of the single-stranded DNA in $20 \mathrm{~min}$ at $58^{\circ} \mathrm{C}$. Under these conditions, less than $5 \%$ of double-stranded DNA was hydrolyzed. Reacted DNA was precipitated with trichloroacetic acid and collected by filtration, and the radioactivity was measured with a Beckman LS 330 liquid scintillation counter.

The DNA base compositions of strains WAL-4 and WAL-13 and of Hyphomicrobium sp. strain T37 were determined from their bouyant densities in $\mathrm{CsCl}$ (9).

Gas chromatography. For gas chromatographic analysis of end-product metabolites, cells were grown in $0.3 \%$ glucose, $0.15 \%$ of both peptone and yeast extract, basal salts, and vitamins. Cells were removed by centrifugation. The supernatant was acidified and analyzed for volatile acids on a column ( 6 feet by $1 / 8$ inch [outer diameter]; about 183 by 0.3 $\mathrm{cm}$ ) containing Porapak Q. The column temperature was $205^{\circ} \mathrm{C}$ and the flame ionization detector was $300^{\circ} \mathrm{C}$. Samples $(1.0 \mathrm{ml})$ of acidified supernatant were methylated and assayed at $145^{\circ} \mathrm{C}$ on a column ( 6 feet by $1 / 4$ inch [outer diameter]; about 183 by 0.6 cm) packed with $15 \%$ of CPE 2225 on Chromosorb W/AW 45/60 mesh (Clinical Analysis Products).

\section{RESULTS}

Occurrence and isolation of the strains. Total viable numbers of lagoon bacteria were routinely determined by plating an appropriate dilution of water from the lagoon on MMB agar. Comparison with direct microscope counts indicated that the viable counts were equal to 25 to $50 \%$ of the total bacterial community. On two separate occasions, wet mounts from numerous colonies were examined by phase microscopy. Approximately 5 to $7 \%$ of the colonies were mushroom-shaped budding bacteria, indicating that the in situ concentrations of viable organisms were $6.4 \times 10^{5}$ and $2.0 \times 10^{6}$ cells per $\mathrm{ml}$. These budding bacteria formed two distinct colony types, suggesting that two different strains were present in the lagoon. Both colony types were round, white, and convex; however, one type was larger and more viscous. The large and small colony types were isolated and desig- 
nated as strains WAL-4 and WAL-13, respectively. In pure-culture studies, the colony morphologies of strains muM and muMA were similar to that of WAL-4.

Growth cycle and morphology. Strains WAL-4 and WAL-13 were morphologically very similar to the two previous isolates muM and muMA (Fig. 1A-D). Slide culture studies indicated that these bacteria reproduced by a bud-

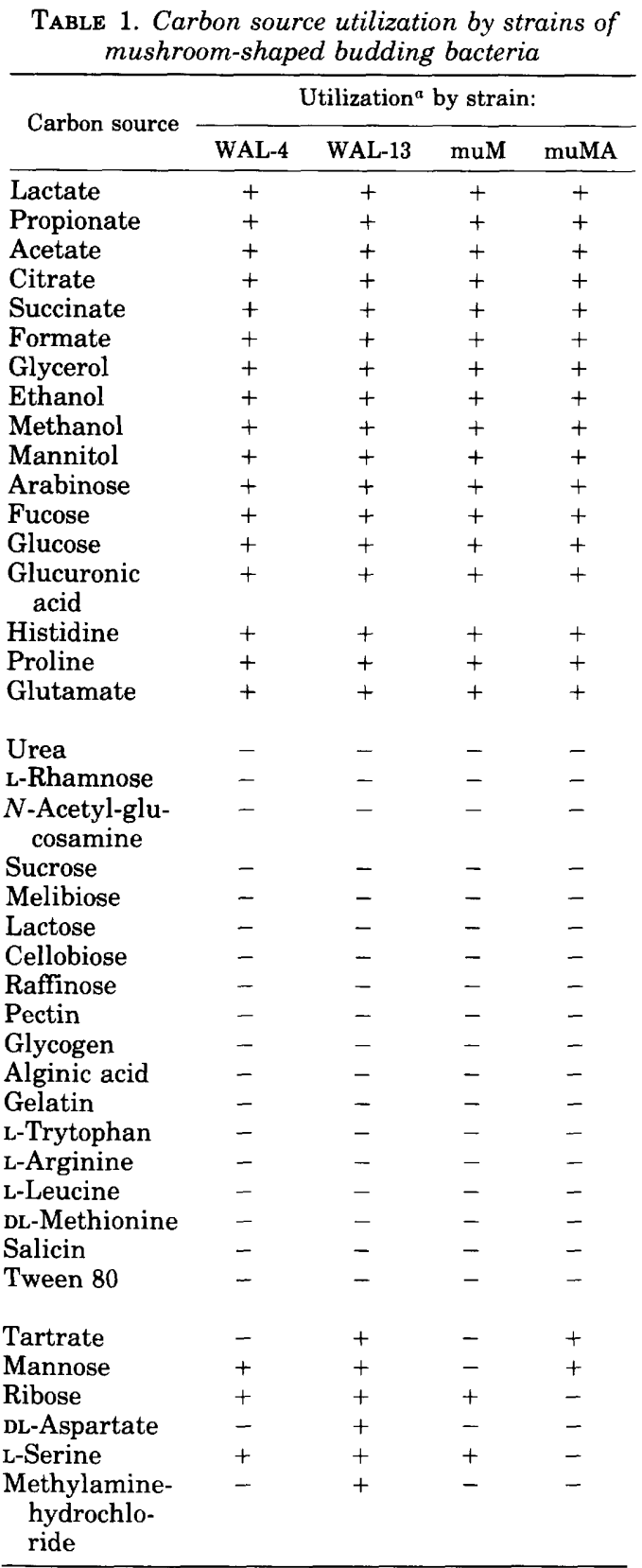

$"+$, Utilized; -, not utilized.
TABLE 2. DNA/DNA homologies of mushroomshaped budding strains and members of currently recognized budding bacteria ${ }^{a}$

\begin{tabular}{lcc}
\hline \multicolumn{1}{c}{ Organism } & $\begin{array}{c}\text { \% Homology } \\
\text { with strain } \\
\text { WAL-4 }\end{array}$ & $\begin{array}{c}\text { DNA base } \\
\text { composition } \\
\text { (mol\% G+C) }\end{array}$ \\
\hline WAL-4 & 100 & $68.4^{b}$ \\
WAL-13 & 85 & 67.9 \\
muM & 39 & $67.7^{c}$ \\
muMA & 41 & $68.2^{c}$ \\
$\begin{array}{l}\text { Hyphomicrobium nep- } \\
\quad \text { tunium ATCC 15444 }\end{array}$ & 0 & $61.7^{d}$ \\
$\begin{array}{l}\text { Hyphomicrobium sp. } \\
\quad \text { strain NQ-521 }\end{array}$ & 0 & $66.8^{d}$ \\
$\begin{array}{l}\text { Hyphomicrobium } \\
\quad \text { sp. }\end{array}$ & 0 & 60.7 \\
$\begin{array}{l}\text { Rhodrain T37 } \\
\text { spheroides strain L-57 }\end{array}$ & & $72.0^{\circ}$ \\
\hline
\end{tabular}

a All reactions were performed in triplicate using ${ }^{3} \mathrm{H}$-labeled WAL-4 DNA with a specific activity of $23,500 \mathrm{cpm} / \mu \mathrm{g}$. Values were adjusted for background obtained with salmon sperm DNA $(14 \%$ of input). Hybridization efficiency was $93 \%$ for the homologous reaction.

${ }^{b}$ Determined by the cesium chloride method by M. Mandel.

' C. S. Dow, personal communication.

${ }^{d}$ For determination, see reference 4.

For determination, see reference 7 .

ding process (Fig. 2). Newly divided organisms (Fig. 2a, upper right clone) were rounded on one side while the area where cell separation had occurred appeared conical. This conical section elongated to form a tube (Fig. 2a, b, upper left clone). It was during these early stages of budding that the cell outline resembled a mushroom. The growing tube then enlarged (Fig. 2c, upper left clone) to produce a dumbbell-shaped organism. Just before cell division, the mother and daughter cells were of equal size (Fig. 2a, lower left clone). The region between the mother and daughter cell constricted and the two cells separated (Fig. 2a, upper right clone; Fig. 2e, lower left clone). Both mother and daughter cells produced lateral buds at the point of cell separation. In contrast to other budding bacteria, the mother and daughter cells appeared to produce buds synchronously (Fig. 2a-f, upper right clone).

Physiology. All four strains were capable of growth in mineral medium with glucose as the sole source of energy and organic carbon. None of the strains grew anaerobically on MMB agar with or without $0.25 \% \mathrm{KNO}_{3}, \mathrm{NaHCO}_{3}$, or $\mathrm{Na}_{2} \mathrm{SO}_{4}$. Organic compounds used as sole sources of carbon and energy by all four strains are listed in the top section of Table 1. Compounds not used by any of the strains are listed in the middle part of Table 1. At the bottom of 
the table are those carbon sources which were utilized by at least one but not by all four of the strains.

By gas chromotographic analysis, it was determined that the four strains of mushroomshaped budding bacteria did not excrete any of the following acids: acetic, propionic, isobutyric, butyric, valeric, caproic, pyruvic, lactic, or succinic. Strain WAL-4 produced an unidentified compound that eluted from Porapak $Q$ between acetic and propionic acids. During assay for nonvolatile acids, it was noted that strain muMA formed small amounts of another unidentified compound.

DNA homology. Results of the DNA reassociation experiments are shown in Table 2. Heteroduplexes were formed between strain WAL4 and the other three strains of mushroomshaped budding bacteria. No reassociation was observed in the reactions of WAL-4 DNA with DNA from the Hyphomicrobium and Rhodopseudomonas strains. In addition, heteroduplexes were not formed when unlabeled DNA from the four strains of mushroom-shaped budding bacteria was reassociated with ${ }^{3} \mathrm{H}$-labeled DNA from Ancalomicrobium adetum, Prosthecomicrobium enhydrum, and Hyphomicrobium strain T37.

Bacteriophages. Two bacteriophages that attack the mushroom-shaped budding strains were isolated from the lagoon. Phages Ev2 and Ev3 formed round, clear plaques on host lawns of WAL-4 and WAL-13, respectively. The phage patterns of the four bacterial strains are shown in Table 3. Phage Ev2 formed clear plaques on the susceptible strains. When growing with strain muM as host, phage Ev3 caused a partial, uneven clearing of the bacterial lawn.

\section{DISCUSSION}

When examined by phase microscopy, the morphologies of the four strains of mushroomshaped budding bacteria were found to be essentially identical. Physiologically, the orga-

TABLE 3. Host ranges of two bacteriophages that infect mushroom-shaped budding bacteria

\begin{tabular}{lcc}
\hline \multirow{2}{*}{ Bacterial strain } & \multicolumn{2}{c}{ Host range $^{a}$ of phage: } \\
\cline { 2 - 3 } & $\operatorname{Ev~} 2^{b}$ & $\operatorname{Ev~}^{b}$ \\
\hline WAL-4 & + & - \\
WAL-13 & - & + \\
muM & + & p \\
muMA & + & - \\
\hline
\end{tabular}

$a+$, Complete clearing of lawn; - , no clearing of lawn; $p$, partial, uneven clearing of lawn.

${ }^{b}$ Phages Ev2 and Ev3 were isolated from aeration lagoon water using as host bacteria strains WAL-4 and WAL-13, respectively. nisms were also very similar. None grew anaerobically with or without nitrate, carbonate, or sulfate. All strains used several monosaccharides, alcohols, and low-molecular-weight acids, as well as certain amino acids as sole carbon and energy sources. Disaccharides, complex carbohydrates, and gelatin were not used by any of the strains. Although similar, the metabolic capabilities of the strains were not identical. Several compounds were used by at least one but not by all four strains. The results of the carbon source tests in this study agreed with previously published results for strains MuM and MuMA with three exceptions: Whittenbury and Nicoll (14) reported that their strain (muM) did not utilize methanol; Namsaraev and Zavarzin (8) reported that strain muMA (their strain 2821) utilized lactose but did not grow with tartrate as the sole carbon and energy source. The variation in results among the three studies may be due to procedural differences in substrate concentration and incubation time.

DNA/DNA homology studies indicated that the four strains are related. The two strains WAL-4 and WAL-13, which coexist in the aeration lagoon, have the greatest degree of DNA homology - 85\%. Strains isolated in England (muM) and Russia (muMA) are related to WAL-4 at the $40 \%$ level of homology. Although strains muM and muMA exhibit similar homology to WAL-4, other characteristics indicate they are not identical to one another. For example, strain muM was susceptible to phage Ev3 whereas muMA was not. Also, the two strains differed in their ability to use various carbon sources.

Although there are several genera of budding bacteria, the mushroom-shaped budding strains showed no relationship to any of the examined members of these genera. No DNA/ DNA reassociation was found between the mushroon-shaped bacteria and Hyphomicrobium sp. strain T37, Hyphomicrobium sp. strain NQ 521, which is related to the group 1 Hyphomicrobium strains (6), Ancalomicrobium adetum, Prosthecomicrobium enhydrum, or Hyphomicrobium neptunium (3).

On the basis of DNA base composition, the mushroom-shaped strains could not be closely related to most of the other known budding bacteria. At $68 \mathrm{~mol} \%$ guanine plus cytosine $(\mathrm{G}+\mathrm{C})$, the mushroom-shaped strains have a higher $\mathrm{G}+\mathrm{C}$ content than Gemmiger formicilis (59 $\mathrm{mol} \% / \mathrm{G}+\mathrm{C}[2])$, Nitrobacter (61 to $62 \mathrm{~mol} \%$ $\mathrm{G}+\mathrm{C}[1]$ ), or group 3 Hyphomicrobium strains (59 to $61 \mathrm{~mol} \% \mathrm{G}+\mathrm{C}$ [4]). The only other budding bacteria which could be related to the mushroom-shaped bacteria are the non-sulfur purple photosynthetic bacteria including $R h o$ - 
dopseudomonas palustris (65 to $66 \mathrm{~mol} \% \mathrm{G}+$ $C), R$. viridis (66 to $71 \mathrm{~mol} \% \mathrm{G}+\mathrm{C}$ ), and $R$. acidophilia (62 to $67 \mathrm{~mol} \% \mathrm{G}+\mathrm{C}$ ) (1). However, the physiology of these organisms is different from that of the heterotrophic mushroomshaped budding bacteria, and thus it is unlikely that the two groups are closely related.

Therefore, it appears that the mushroomshaped budding bacteria are unrelated to any of the members of the previously described genera of budding bacteria. Since the four mushroomshaped budding strains are very similar to each other in terms of morphology and physiology, it seems unnecessary to divide the strains into more than one genus at this time. We conclude that a new genus and species should be proposed for these mushroom-shaped budding bacteria and it is our understanding that such a proposal will be published shortly (C. S. Dow, personal communication).

\section{ACKNOWLEDGMENTS}

We wish to thank Crawford Dow and Kevin Marshall for furnishing bacterial strains. Thanks are also extended to Manley Mandel for determining the base composition of strain WAL-4 and to Crawford Dow for making available unpublished data on the DNA base composition of strains muM and muMA. Fred Howard of the Weyerhaeuser Co. (Everett Kraft Mill, Everett, Wash.) was very helpful in supplying water samples. We appreciate the technical assistance of Emilia DiBlasio and Robert Bigford. This work was supported in part by Public Health Service Training Grant GM 00511 from the National Institute of General Medical Sciences and by National Science Foundation Grant GB-30313.

\section{REPRINT REQUESTS}

Address reprint requests to: Dr. Patricia M. Stanley, Department of Microbiology, University of Minnesota, Minneapolis, Minn. 55455.

\section{LITERATURE CITED}

1. Buchanan, R., and N. Gibbons (ed.). 1974. Bergey's manual of determinative bacteriology, 8th ed. Williams and Wilkins Co., Baltimore.

2. Gossling, J., and W. E. C. Moore. 1975. Gemmiger formicilis, n. gen., n. sp., an anaerobic budding bacterium from intestines. Int. J. Syst. Bacteriol. 25:202-207.

3. Leifson, E. 1974. Hyphomicrobium neptunium sp. n. Antonie van Leeuwenhoek J. Microbiol, Serol 30:249-256.

4. Mandel, M., P. Hirsch, and S. F. Conti. 1972. Deoxyribonucleic acid base composition of hyphomicrobia. Arch. Mikrobiol. 81:289-294.

5. Marmur, J. 1961. A procedure for isolation of deoxyribonucleic acid from microorganisms. J. Mol. Biol. 3:208-218.

6. Moore, R. L., and P. Hirsch. 1972. Deoxyribonucleic acid base sequence homologies of some budding and prosthecate bacteria. J. Bacteriol. 110:256-461.

7. Moore, R. L., and B. J. McCarthy. 1969. Characterization of the deoxyribonucleic acid of various strains of halophilic bacteria. J. Bacteriol. 99:248-254.

8. Namsaraev, B. T., and G. A. Zavarzin. 1973. Trophic relationships in a methane-oxidizing culture. Microbiology 42:887-892.

9. Schildkraut, C. L., J. Marmur, and P. Doty. 1962. Determination of the base composition of deoxyribonucleic acid from its buoyant density in $\mathrm{CsCl}$. J. Mol. Biol. 4:430-433.

10. Staley, J. T. 1968. Prosthecomicrobium and Ancalomicrobium: new prosthecate freshwater bacteria. J. Bacteriol. 95:1921-1942.

11. Staley, J. T., and M. Mandel. 1973. Deoxyribonucleic acid base composition of Prosthecomicrobium and $A n$ calomicrobium strains. Int. J. Syst. Bacteriol. 23:271273.

12. Tyler, P. A., and K. C. Marshall. 1967. Pleomorphy in stalked, budding bacteria. J. Bacteriol. 93:1132-1136.

13. Van Ert, M., and J. T. Staley. 1971. Gas-vacuolated strains of Microcyclus aquaticus. J. Bacteriol. 108:236-240.

14. Whittenbury, R., and J. Nicoll. 1971. A new, mushroom-shaped budding bacterium. J. Gen. Microbiol. 66:123-126. 